\title{
The Hematology of Lactating Buffalo Fed Local Foliage as Feed Supplement
}

\author{
Elly Roza, Salam Ningsih Aritonang and Afriani Sandra \\ Animal Production Department, Animal Science Faculty, Andalas University, Limau Manis, Padang 25163, West Sumatera, \\ Indonesia
}

\begin{abstract}
The research aimed to determine the effect of feed supplements of cassava (Manihot esculenta Crantz) leaves, gliricidia (Gliricidia sepeum) leaves and katuk (Sauropus androgynus (L.) Merr.) leaves on the hematology of lactating buffalo. Four lactating buffaloes in Kanagarian Pamatang Panjang, Sijunjung district, West Sumatera, Indonesia were studied. The experiment used a Latin square design with four treatments and four replications/block. The treatments were control (without supplementary foliage, A), with cassava leaves (B), with gliricidia leaves (C) and with katuk leaves (D) each at $5 \mathrm{~kg} / \mathrm{head} / \mathrm{day}$. The hematology variables measured were erythrocytes and leucocytes counts, as well as levels of hemoglobin and hematocrit. The results showed that supplementary foliage of $5 \mathrm{~kg} / \mathrm{head} /$ day of cassava, gliricidia or katuk as leaves significantly increased the erythrocytes count and hemoglobin level, but did not affect the number of leucocytes in lactating buffalo.
\end{abstract}

Key words: Cassava leaves, gliricidia leaves, katuk leaves, buffalo, haematology, lactation.

\section{Introduction}

Although the swamp buffalo is not a specialized dairy animal in several regions in Indonesia, like West Sumatra, they are used for milk production [1, 2]. Traditional methods are used in the raising of these ruminants in Indonesia, and the availability of feed is one of the factors determining the success and sustainability of animal production. Feed directly affects production, productivity and health of livestock [3].

Low milk production can be caused by genetic factors, conditions of maintenance and quality of feed, and indirectly less than the optimal blood hematology [4]. Utilization of nutrients in the body involves the role of blood which transports nutrients to the sites of biosynthesis, where energy, meat and milk are produced.

Blood can be used to help measure livestock physiological condition. The level of erythrocytes, leucocytes and platelets reflects the condition of the

Corresponding author: Elly Roza, Ph.D., research field: dairy production. animal. Blood is used to the transport the components in the body, such as nutrients, oxygen, carbon dioxide, metabolites, hormones, and components of the body immune system. Feed is essential for the metabolism of blood, because it contains protein, vitamins and minerals needed in the formation of red blood cells [5]. The formation of erythrocytes involves many processes that require protein, iron, copper and cobalt in sufficient quantities in the feed [6]. To achieve normal hematology, conditions can be improved by using supplements to cover the deficiencies in the basic feed [7].

Cassava (Manihot esculenta Crantz) leaves have a higher protein content than stalks and stems [8]. Cassava leaves as hay can be directly fed or as a component of concentrate mixture [9] or pellets with soy flour and urea, or component in block form [10].

Katuk (Sauropus androgynus (L.) Merr.) leaves have long been known to the Indonesia people as a vegetable crop with high nutritional content. The main use of katuk leaves in the traditional medicine is to supplement human breast milk [11]. Katuk leaves as powder or extract can increase milk production in 
ewes [12]. The chemical constituents of katuk leaves include tannins, catechins, flavonoids, alkaloids, triterpenes, organic acids, essential oils, saponins, sterols, amino acids, proteins, carbohydrates, vitamins and minerals [13].

Gliricidia (Gliricidia sepium) leaves are a legume crop that can grow rapidly in dry areas. Gliricidia is a high protein animal feed with protein content higher than that of standard concentrate, which has a $17 \%$ maximum protein content. Gliricidia leaves protein is highly digestible by ruminant. The guideline for the presence of gliricidia leaves is up to $40 \%$ in cattle feeding and $75 \%$ for sheep. Gliricidia leaves should be combined with grass for ruminants $[14,15]$.

These chosen traditional crops have potential as healthy food supplements and this study was conducted to investigate their impact on some hematological measurement as indication of health status of buffalo.

\section{Materials and Methods}

This research was conducted in Kanagarian Pamatang Panjang, Sijunjung district, West Sumatra, Indonesia. Traditionally farm used lactating swamp buffalo between the age of 4-5 years. The design used was a Latin square design with four treatments, i.e., without additional foliage (A), cassava leaves (B), katuk leaves (C) and gliricidia (D) and four replications per treatments.

\subsection{The Chemical Composition of the Foliages}

Cassava leaves contain moisture $84.4 \%$, protein
$6.2 \%$, fat $1.1 \%$, carbohydrate $7.1 \%$, fiber $2.4 \%$, ash $1.2 \%$, Ca $1.66 \%$, P $0.99 \%$, Fe 1.3\%, $\mathrm{VB}_{1} 0.14 \mathrm{mg}$ and VC $130.0 \mathrm{mg}$. Gliricidia leaves contain moisture $74.56 \%$, protein $6.16 \%$, fat $1.18 \%$, fiber $10.27 \%$, ash 2.3\%, Ca $1.55 \%$, and P $0.06 \%$. Katuk leaves contain moisture $81 \%$, protein $4.8 \%$, fat $1 \%$, carbohydrate 11\%, Ca $2.04 \%$, P $0.83 \%$ and Fe $0.03 \%$. Forage and concentrates are given following the methods used by the farmer. The feed composition is shown in Table 1.

\subsection{Research Procedure}

This study used four buffaloes (Latin square design) in their 2nd lactation period during the 3rd and 4th month of lactation. Katuk leaves were given fresh, while cassava leaves and gliricicidia leaves were withered first with $5 \mathrm{~kg} / \mathrm{head}$ fed out at each morning, followed by $3 \mathrm{~kg}$ of concentrate. In the daytime, the buffalo foraged in the field. A period of adaption was allowed so that the buffalo could adjust to the livestock feed regime which lasted for two weeks. This period lasts for three month. First, one treatment was used for two week, next one week for adaptation after receiving the first treatment, and then the next two week the animal received the subsequent treatment.

\subsection{Data Collection}

The variables measured in this study was the hematology of lactating buffalo, including the erythrocytes and leucocytes count, as well as levels of hemoglobin and hematocrit. Hematological variables were selected in this study to investigate the impact of

Table 1 Composition of the research buffalo feed.

\begin{tabular}{llllll}
\hline \multirow{2}{*}{ No. } & $\begin{array}{l}\text { Feed composition } \\
(\mathrm{kg})\end{array}$ & $\mathrm{A}$ & $\mathrm{B}$ & $\mathrm{C}$ & $\mathrm{T}$ \\
\cline { 3 - 6 } & Forage & Field grass & Field grass & Field grass & Field grass \\
\hline 1 & Concentrate & & & & 2.0 \\
\hline & Tofu dregs & 2.0 & 2.0 & 2.0 & 2.0 \\
& Bran & 2.0 & 2.0 & 0.5 & 0.5 \\
& Corn & 0.5 & 0.5 & 0.5 & - \\
& Coconut oilcake & 0.5 & 0.5 & - & - \\
& Cassava leaves & - & 5.0 & 5.0 & 5.0 \\
\hline
\end{tabular}


anti-nutrients that contained in the foliages on the health of livestock. The value of hematology indicates the health of buffalo. Measurement is done by taking $10 \mathrm{~mL}$ of blood from the jugular vein, using a syringe needle 20 gauge with capacity $10 \mathrm{~mL}$, and $1 \mathrm{~mL}$ of blood was inserted into a Venoject tube containing a solution of heparin as anticoagulant. After that, each tube was inserted into an auto hematology analyzer Mindray BC-3200.

The data obtained were analyzed using analysis of variance (ANOVA). If there is a difference between treatments, the comparison of treatment means was followed by Duncan's multiple range test.

\section{Results and Discussion}

\subsection{Erythrocyte Count}

Statistical analysis showed that the erythrocyte count in lactating buffalo was significantly $(P<0.01)$ influenced by the foliage supplement. The erythrocyte in buffalo fed on cassava leaves (treatment B) was the highest $\left(9.05 \pm 0.60 \times 10^{6} / \mu \mathrm{L}\right)$, followed by treatment $\mathrm{C}$ $\left(8.08 \pm 0.63 \times 10^{6} / \mu \mathrm{L}\right), \mathrm{D}\left(7.03 \pm 0.33 \times 10^{6} / \mu \mathrm{L}\right)$, and the lowest in treatment $\mathrm{A}$ is $6.35 \pm 0.35 \times 10^{6} / \mu \mathrm{L}$ (Table 2). Foliage supplements increased the erythrocyte count to a higher level within the normal range in buffalo. The erythrocyte count of normal lactating buffalo ranges from $5.07 \times 10^{6} / \mu \mathrm{L}$ to $10.25 \times 10^{6} / \mu \mathrm{L}$ [16]. The value of erythrocyte count is higher than the lactating buffalo $\left(8.80 \times 10^{6} / \mu \mathrm{L}\right)$ fed cassava leaves in pellet form [2].

This increase in the erythrocyte count is thought to have occurred because of the content of the compounds, such as proteins, minerals $\mathrm{Fe}, \mathrm{Cu}$ and Co contained in the foliage supplement. The compounds

Table 2 The erythrocyte count in lactating buffalo.

\begin{tabular}{lll}
\hline Treatment & Mean $\left(\times 10^{6} / \mu \mathrm{L}\right)$ \\
\hline $\mathrm{A}$ & $6.35 \pm 0.35^{\mathrm{d}}$ \\
$\mathrm{B}$ & $9.05 \pm 0.60^{\mathrm{a}}$ \\
$\mathrm{C}$ & $8.08 \pm 0.63^{\mathrm{b}}$ & \\
$\mathrm{D}$ & $7.03 \pm 0.33^{\mathrm{c}}$ & \\
${ }_{\mathrm{a}-\mathrm{d}}$ Values with different & superscript indicate & significant \\
difference at $P<0.01$. & &
\end{tabular}

are related to the formation of erythrocytes. The process of erythrocyte formation requires these compounds as precursors [2, 17].

The highest erythrocyte count came from lactating buffalo fed cassava leaves (B), because cassava leaves contain a higher level of protein (25\%-27\%) than the katuk leaves (20\%-23\%) and a better balance of amino acids. In addition, amino acids and tannin in cassava leaves can help the microbial synthesis in the rumen, which will indirectly affect erythrocyte formation. The indirect effect of condensed tannins in cassava leaves is an increase of protein supply to the gastrointestinal tract [18]. Condensed tannin in foliage has a good influence on ruminant protein, leading to enhanced nutrition and red blood cell formation [19]. Consequently, the erythrocytes of lactating buffalo fed cassava leaves (B) are higher than lactating buffalo fed katuk leaves.

The erythrocyte count of lactating buffalo fed cassava leaves is also higher than lactating buffalo fed gliricidia leaves, whereas protein content of gliricidia leaves is much higher (31.97\%-35.92\%) than the cassava leaves (25\%-27\%). This is due to ruminants' able to manipulate anti-nutrients contained in the cassava leaves, resulting in a higher availability of the protein in cassava compared to gliricidia. This adding can increase the consumption of foliage with low quality and increase the productivity of ruminants, especially in milk production and weight gain [19].

The erythrocyte count in treatment A (control) is the lowest $\left(6.35 \pm 0.35 \times 10^{6} / \mu \mathrm{L}\right)$. This is caused by the fact that the buffalo only consume forage available in pastures, like star grass/Cynodon nlemfuensis (8.62\% crude protein) and wild grass/Imperata cylindrical (2.8\% crude protein). This low level of nutrient in the diet is not sufficient for the production of a maximal number of red blood cells, because lactating cattle require $13 \%-15 \%$ crude protein [20]. Consequently, the number erythrocytes formed in treatment $\mathrm{A}$ is the lowest. 


\subsection{Hemoglobin Level}

Statistical analysis showed that the hemoglobin levels of lactating buffalo was significantly $(P<0.01)$ influenced by the foliage supplements. The hemoglobin in lactating buffalo fed cassava leaves (treatment B) is the highest $(13.33 \pm 0.80 \mathrm{~g} / \mathrm{dL})$, followed by treatment $\mathrm{C}(12.35 \pm 1.45 \mathrm{~g} / \mathrm{dL}), \mathrm{D}(11.28$ $\pm 1.15 \mathrm{~g} / \mathrm{dL}$ ), and the lowest is treatment $\mathrm{A}$ at $9.68 \pm$ $0.05 \mathrm{~g} / \mathrm{dL}$. Table 3 shows the hemoglobin count resulting from different feed supplements in lactating buffalo hemoglobin.

Cassava leaves, katuk leaves and gliricidia leaves increased the hemoglobin levels probably because these contain high protein and iron (Fe). Hemoglobin is a combination of heme and globin. Heme is formed from $\mathrm{Fe}$ in the mitochondria, while the globin is formed from protein [21]. Thus, supplementary feed, such as cassava leaves, katuk leaves and gliricidia leave on lactating buffaloes will produce a higher number of hemoglobin compared to lactating buffalo who are not given these supplements.

The hemoglobin level of lactating buffalo fed cassava leaves (B) is higher than lactating buffalo fed gliricidia leaves (D), even though the protein content of gliricidia leaves is much higher (31.97\%-35.92\%) than the cassava leaves (25\%-27\%). This is possibly because cassava leaves also contain condensed tannins, which indirectly increase the supply of protein to the gastrointestinal tract and thus improve the quality of protein [22]. Thus, although protein content of cassava leaves is lower than gliricidia leaves, its quality is higher with the presence of tannins. Consequently, the hemoglobin level produced by lactating buffalo fed cassava leaves was higher than lactating buffalo fed gliricidia leaves, wherein the protein is more easily converted into hemoglobin-forming material.

The hemoglobin level of lactating buffalo fed cassava leaves (B) is higher (25\%-27\%) than lactating buffalo fed katuk leaves (C) (20\%-23\%). This is probably because the protein content of cassava leaves is higher than katuk leaves. There are some substances that play a role in the formation of hemoglobin, including $\mathrm{Fe}$ protein, vitamin $\mathrm{B}_{6}$, which acts as a catalyst in the synthesis of heme in the hemoglobin molecule. That is why the hemoglobin levels of lactating buffalo fed cassava leaves was higher than hemoglobin levels of lactating buffalo fed katuk leaves.

The hemoglobin level of lactating buffalo in these research is 9.68-13.33 g/dL within the normal range, as determined between $9 \mathrm{~g} / \mathrm{dL}$ and $13.5 \mathrm{~g} / \mathrm{dL}$ by Jain [23].

\subsection{Hematocrit Level}

Statistical analysis showed that the hematocrit level in lactating buffalo was significantly $(P<0.01)$ influenced by foliage supplement. The hematocrit level in lactating buffalo fed cassava leaves (treatment $\mathrm{B})$ is the highest $(38.00 \% \pm 0.96 \%)$, followed by treatment C $(31.30 \% \pm 1.30 \%)$ and $\mathrm{A}(29.30 \% \pm$ $1.22 \%)$, but not significantly different $(P>0.05)$ with treatment $\mathrm{D}(36.40 \% \pm 1.10 \%)$. The influence of feed supplements on the hematocrit level of lactating buffalo is shown in Table 4.

Increased hematocrit levels in lactating buffaloes fed cassava leaves, katuk leaves and gliricidia leaves occur, because nutrients and minerals in these supplements

Table 3 Hemoglobin levels in lactating buffalo.

\begin{tabular}{llll}
\hline Treatment & Mean $(\mathrm{g} / \mathrm{dL})$ & \\
\hline $\mathrm{A}$ & $9.68 \pm 0.05^{\mathrm{a}}$ & \\
$\mathrm{B}$ & $13.33 \pm 0.80^{\mathrm{d}}$ & \\
$\mathrm{C}$ & $12.35 \pm 1.45^{\mathrm{c}}$ & \\
$\mathrm{D}$ & $11.28 \pm 1.15^{\mathrm{b}}$ & \\
\hline $\mathrm{a}-\mathrm{d}$ Values with different & superscript indicate & significant \\
difference at $P<0.01$. & &
\end{tabular}

\section{Table 4 The hematocrit levels in lactating buffalo.}

\begin{tabular}{lll}
\hline Treatment & Mean (\%) & \\
\hline $\mathrm{A}$ & $29.30 \pm 1.22^{\mathrm{b}}$ & \\
$\mathrm{B}$ & $38.00 \pm 0.96^{\mathrm{a}}$ & \\
$\mathrm{C}$ & $31.30 \pm 1.30^{\mathrm{b}}$ & \\
$\mathrm{D}$ & $36.40 \pm 1.10^{\mathrm{a}}$ & \\
${ }_{\mathrm{a}-\mathrm{b}}$ Values with different & superscript indicate & significant \\
difference at $P<0.01$. & &
\end{tabular}


have a major role in normal growth and maturity of erythrocytes and hematocrit. Hematocrit indicates the volume of red blood cells or whole erythrocytes within $100 \mathrm{~mm}^{3}$ of blood expressed as a percent [17].

The hematocrit level in lactating buffalo fed cassava leaves on treatment $B$ is higher than treatment $\mathrm{C}$ and $\mathrm{A}$, but not significantly different than treatment D. This is probably because the protein content in cassava leaves and gliricidia leaves is higher than treatment $\mathrm{C}$ and $\mathrm{A}$; protein is one of the components needed in forming red blood cells, and hematocrit is a measure of the concentration of erythrocytes [24]. That is why the hematocrit number of lactating buffaloes fed cassava leaves (B) and gliricidia leaves (D) is higher than number of hematocrit lactating buffaloes fed katuk leaves (C) and without foliage supplement feeding (A/control). Hematocrit levels depend on the number of erythrocytes. Erythrocytes and hematocrit values are parallel to each other.

Hematocrit of lactation buffalo in this study (29.30\%-38.00\%) is within the normal range as determined between $26.00 \%$ and $38.00 \%$ by Jain [23].

\subsection{Leucocytes Count}

Statistical analysis showed that the supplemental feeding (cassava leaves, katuk leaves and gliricidia leaves ) did not affect the leucocytes count of lactating buffalo. The values were 6.00-7.95 $\times 10^{3} / \mu \mathrm{L}$ (Table 5). These leukocyte counts are in the normal range as determined between $6.25 \times 10^{3} / \mu \mathrm{L}$ and $13.05 \times$ $10^{3} / \mu \mathrm{L}$ by Jain [23].

There appears to be no negative effect on leucocyte levels from foliage feeding of cassava leaves, katuk leaves and gliricidia leaves. In fact, the vitamin A, vitamin $\mathrm{C}$ and flavonoids which can act as antioxidant

Table 5 The leucocytes count in lactating buffalo.

\begin{tabular}{ll}
\hline Treatment & Mean $\left(\times 10^{3} / \mu \mathrm{L}\right)$ \\
\hline A & $7.95 \pm 0.56$ \\
B & $6.00 \pm 0.43$ \\
C & $6.35 \pm 0.39$ \\
D & $6.68 \pm 0.29$ \\
\hline
\end{tabular}

may will protect the cattle from infection, and thus would raise leucocytes levels. Antioxidants control the presence of the pathogens and the number of leukocytes in the blood remains stable [25].

Leukocytes are a blood component playing a role in the immune and body defense system. Leucocytes' function is to provide antibodies in the defense system that is fast and powerful against infection. The number of white blood cells (leucocytes) will increase generally when the body is infected by microorganisms [26]. Therefore, the stable number of leucocytes in lactating buffaloes fed these leaves is positive result.

The result of this research showed that according to haematological measures of lactating buffalo, cassava leaves are the best of these supplemental foliages, presumably because the role of condensed tannins contained in cassava leaves. These tannins can reduce the faecal eggs count indicating a higher health status of livestock [27]. Likewise, the research result of Aritonang and Roza [28] showed that in goats feeding up to $8 \%$ body weight of cassava leaves has reduced faecal eggs count.

\section{Conclusions}

Lactating buffalo fed supplement foliage of cassava, katuk or gliricidia leaves can increase the levels of erythrocytes, hemoglobin and hematokrit in the blood, but has no influence on the leucocyte levels which remain within the normal range. From these types of supplementary foliage, cassava leaves appear to be the most effective. Cassava leaves are easily available and provide the additional health benefits of tannins. Feeding lactating buffalo cassava leaves may be a key to improve the milk production from buffalos in West Sumatera or other similar tropical regions.

\section{Acknowledgments}

The authors are very grateful for the financial support of Ministry of High Education of Indonesia No: DIPA-023.04.1.673453/2015. 


\section{References}

[1] Ibrahim, L. 2008. "Milk Production, Reproduction and Management of Dairy Buffalo in West Sumatra.” Animal Journal 5 (1): 1-9.

[2] Roza, E., Suardi, M. S., Nurdin, E., and Aritonang, S. N. 2013. "Digestibility Test of Cassava Leaves in Feed Suplement of Buffaloes by in Vitro.” Pakistan Journal of Nutrition 12 (5): 505-9.

[3] Ma’sum, M. 2011. General Guidelines for Optimizing Seed in Farmer. Jakarta: Gramedia Press.

[4] Hogberg, M. G., Falest, S. L., Kirschenmann, F. L., Honeyman, M., Miranowski, J., and Lasley, P. 2005. "Interrelationships of Animal Agriculture, the Environment and Rural Communities.” J. Anim. Sci. 83 (13): E13-E17.

[5] Frandson, R. D. 1992. Anatomy and Physiology of Animal. Translated by Srigandono, B., and Praseno, K. Yogyakarta: Gadjah Mada University Press.

[6] Johnson, K. E. 1994. Capita Selecta Series of Histology and Biology of Cell. Translated by Gunawijaya, A. Jakarta: Binarupa Aksara Press.

[7] Tangdilintin, F. K. 2002. "Feed Supplement.” Presented at Short Course on Technology Usage of Radioimmunoassay (RIA) and Urea Molasses Multi-nutrient Block (UMMB) in Animal Reproduction Biology, Cooperation of Animal Science Faculty, Hasanuddin University with Directorate General of Higher Education National Education Department, Makassar.

[8] Borin, K., Chhay, T., Ogle, R. B., and Presston, T. R. 2005. "Research on the Use of Cassava Leaves for Livestock Feeding in Cambodia." In Proceeding of the Regional Workshop on "The Use of Cassava Roots and Leaves for On-Farm Animal Feeding”, 17-9.

[9] Kiyothong, K., and Wanapat, M. 2004. "Growth, Hay Yield and Chemical Composition of Cassava and Stylo 184 Grown under Intercropping.” Asian-Australasian J. Anim. Sci. 17 (6): 799-807.

[10] Wanapat, M., and Khampa, S. 2006. "Effect of Cassava Hay in High-Quality Feed Block as Anthelmintics in Steers Grazing On Ruzi Grass.” Asian-Australasian J. Anim. Sci. 19 (5): 695-8.

[11] Malik, A. 1997. "Phytochemicals Reviews: Indications and Usage Bioactivity of Katuk Leaves and Trengguli Fruit.” Plant Medicine Journal 3 (3): 39-40.

[12] Suprayogi, A., Meulen, U., Ungerer, T., and Manalu, W. 2001. "Population of Secretory Cells and Synthetic Activities in Mammary Gland of Lactating Sheep after Consuming Sauropus androgynus (L.) Merr. Leaves.” Indon. J. Trop. Agric. 10 (1): 1-3.

[13] Zuhra, C. F., Tarigan, J., and Sitohang, H. 2008. “The Activity and Antioxidant of Flavonoid Compound from
Katuk (Sauropus androgunus (L.) Merr.) Leaves.” Journal of Sumatera Biology 3 (1): 7-10.

[14] Wirdahayati, R. B., and Bamualim, A. M. 2007. "Utilization of Gamal (Gliricidia septium) Leaves as Feesd Supplements of Buffalo Manufacturer Curd in West Sumatera." Presented at National Workshop on Buffalo Livestock Business, Indonesian Center for Agricultural Technology Assessment and Development of Bogor, Centre for Research and Development of Animal Husbandry, Bogor.

[15] Wahiduddin, M. 2008. "Science Feed." Accessed December 3, 2011. http://wah1d.wordpress.com/category /science-feed.

[16] Jain, N. C., Vegad, J. L., Jain, N. K., and Shrivastava, A. B. 1982. "Haematological Studies on Normal Lactating Indian Water Buffaloes.” Res. Vet. Sci. 32 (1): 52-6.

[17] Hoffbrand, A. V., and Pettit, J. E. 1996. Capita Selecta of Hematologi. Translated from Essential Hematology and Translated by Darmawan, I. Jakarta: EGC Publisher.

[18] Wanapat, M. 2009. "Potential Uses of Local feed Resources for Ruminant.” Tropical Animal Health and Production 41 (7): 1035-49.

[19] Niezen, J. H., Charleston, W. A., Hodgson, J., Mackay, A. D., and Leathwick, D. M. 1996. "Controlling Internal Parasites in Grazing Ruminants without Recourse to Anthelmintics: Approaches, Experiences and Prospects.” Int. J. Parasitol. 26: 983-92.

[20] National Research Council (NRC). 2001. Nutrient Requirement of Dairy Cattle. Washington, D.C.: National Academy Press.

[21] Eijkman Institute. 2005. “Thalassemia.” Accessed August 7, 2011. http://www.eijkman.go.id.

[22] Athanasiadou, S., Kyriazakis, I., Jackson, F., and Coop, R. L. 2000. "Effects of Short-Term Exposure to Condensed Tannins on Adult Trichostrongylus colubriformis." Vet. Rec. 146 (25): 728-32.

[23] Jain, N. C. 1993. Essential of Veterinary Hematology. Philadelphia, PA: Lea \& Febiger Publisher, 24-36.

[24] Natalia, R. D. 2008. "The Erythrocytes Count, Hematocrit and Hemoglobin Values of Broiler Age Six Weeks Fed Supplements Turmeric, Garlic and Zink.” M.Sc. thesis, Faculty of Veterinary Medicine, Bogor Agricultural Institute.

[25] Rukayah, S. 2008. "Picture of White Blood Cells in Rabbits Vaccinated with Warts Extract of Rhipicephalus sanguineus." M.Sc. thesis, Faculty of Veterinary Medicine, Bogor Agricultural Institute.

[26] Sukardi, M. 2005. "Feed Protein Metabolism and the Rate of Decrease Production Fed Sauropu androgynus Merr. (Katuk) on Friesian Holstein (FH) Dairy Cattle Rations.” M.Sc. thesis, Diponegoro University. 
[27] Granum, G. M., Wanapat, M., Pakdee, P., and Wachirapakorn, C. 2002. "The Effect of Cassava Hay Supplementation on Weight Change, Dry Matter Intake, Digestibility and Intestinal Parasites in Swamp Buffaloes (Bubalus bubalis) and Cattle (Bos indicus).” In
Proceedings of the Agriculture Conference, 30-3.

[28] Aritonang, S. N., and Roza, E. 2015. "Potency of Fresh Cassava (Manihot esculenta Crantz) Leaves as Natural Anthelminthic on Goat Performances.” Pakistan Journal of Nutrition 14 (6): 358-61. 